\title{
Analysis of Core Entrepreneurial Competencies of College Students - Empirical Research Based on Hierarchical Analysis
}

\author{
You Zhensheng ${ }^{1}$, Yang $\mathrm{Liu}^{2, *}$ \\ ${ }^{1}$ School of Foreign Languages and Cultures, Chongqing University, Chongqing, China \\ ${ }^{2}$ Research Center for Preschool Education Development, Shaanxi Xueqian Normal University, Xi'an, China \\ Email address: \\ 983137680@qq.com (Yang Liu) \\ ${ }^{*}$ Corresponding author
}

To cite this article:

You Zhensheng, Yang Liu. Analysis of Core Entrepreneurial Competencies of College Students - Empirical Research Based on Hierarchical Analysis. Higher Education Research. Vol. 4, No. 1, 2019, pp. 16-25. doi: 10.11648/j.her.20190401.12

Received: January 30, 2019; Accepted: March 20, 2019; Published: May 6, 2019

\begin{abstract}
College entrepreneurial talents are the potential power of entrepreneurial activity, and their core competencies have directly decisive impacts on entrepreneurship. Based on literature research, this paper constructs core competencies of entrepreneurial talents from four dimensions, namely, entrepreneurial awareness, entrepreneurial knowledge, entrepreneurial ability and entrepreneurial quality. Exploratory factor analysis and confirmatory factor analysis are used to verify the dimension of scale and analytic hierarchy process is applied to explore the importance of each core competency. It is found that college entrepreneurial talents are weak in entrepreneurial awareness and unfaithful in entrepreneurial attitude, that their entrepreneurial ability and quality are heavily weighted but of low level, that they develop in a balanced way as a whole and have abundant entrepreneurial knowledge after comparing the core competencies of college entrepreneurial talents with those of entrepreneurs by using the questionnaire survey. Therefore, colleges and universities should carry out tribulations training, organize entrepreneurs to exchange their entrepreneurial experiences with students, implement entrepreneurial education, promote entrepreneurial practice, implement entrepreneurial policies and provide opportunities for entrepreneurship.
\end{abstract}

Keywords: College Entrepreneurial Talents, Successful Entrepreneurs, Core Competencies

\section{Introduction}

Under the background of the strategy of rejuvenating the country through science and education, China's colleges and universities have begun to expand enrollment since the end of the 20th century. According to data released by the Ministry of Education, the growth rate of college graduates was $3.88 \%$ in $2014,7.68 \%$ in 2015 , and $4.69 \%$ in 2016 . The number of college graduates in 2017 even reached 7.59 million [1], and consequently, the employment problem of college graduates caused wide social concerns. In recent years, encouraged by the government policies, increasingly more undergraduates have chosen to start their own businesses with $1.0 \%$ in 2008 to $2.9 \%$ in 2017 [2]. However, the results show that less than $5 \%$ of college graduates successfully made their businesses, which is far behind the social expectations. Among the many factors that affect the successful entrepreneurship of college graduates, self- quality is of vital importance and worthy of being explored.

Previous research on entrepreneurial talents mostly explored the training mode from a macro perspective, paying little attention to the core competencies of entrepreneurial talents. However, according to the theory of internal and external factors, internal factors are the basis for the development of things [3]. Therefore, core competencies, as the internal factors underlying college students' entrepreneurial activities, are the key factors to determine the success or failure of entrepreneurship. Based on literature review, this paper constructs the core competency model of entrepreneurial talents from the four dimensions of entrepreneurial awareness, entrepreneurial knowledge, entrepreneurial ability and entrepreneurial quality, and compiles a questionnaire. This paper uses the exploratory factor analysis and confirmatory factor analysis to test the 
reliability and validity of the questionnaire which we use to investigate core competencies of college entrepreneurial talents. Another highlight of this paper is to use the same questionnaires to investigate the core competencies of successful entrepreneurs, and use the analytic hierarchy process to explore the order of importance of each core literacy. Based on the analysis of the statistics, the paper offers suggestions for the cultivation of the core competencies of college entrepreneurial talents, claiming that targeted training in entrepreneurship can better satisfy the needs of the students and boost the success rate of the students' entrepreneurial practices.

\section{Literature Review}

\subsection{Core Concepts}

\subsubsection{College Entrepreneurial Talents}

Robert, D. Hisrich, an American scholar, believes that "Entrepreneurship is a process to create different values by investing the necessary time and energy, taking on the corresponding financial, psychological and social risks and accepting the rewards both in the forms of money and individual psychological satisfaction [4]." In this process, entrepreneurial talents, who are the practical subjects, apply their own knowledge, ability and resources to create a new product or provide a new service, and ultimately achieve their ideals and values. In recent years, more and more college students tend to start their own businesses in a society that encourages innovation and entrepreneurship. Society and colleges should give top priority to these potential entrepreneurs as they turn knowledge and technology into wealth and they are important forces to promote industrial development. The research object of this paper is college entrepreneurial talents, more specifically, the college students with entrepreneurial ideals tending to start their own businesses after graduation.

\subsubsection{Core Competency}

"Core competency" was first proposed by the Organization for Economic Co-operation and Development (OECD) and is involved in many fields. In the United States, people's focus on core competencies stems from high-tech enterprise teams that attach great importance to knowledge innovation. And these enterprise teams feed back the problems encountered in the employment to education, pointing out that the basic education should lay stress on cultivating qualities and abilities that qualified employees should have [5], which can be regarded as the requirements of enterprises for talents' quality. In China, "The Core Competencies of Chinese Students' Development" defines "core competencies of student development" as "the essential characters and key abilities that students must have to adapt to lifelong development and social development [6]". Hence, "core competency" becomes a hot topic in educational circles. The core competencies of entrepreneurial talents not only involve the students' development competencies, but also the basic requirements of entrepreneurial activities on talent competencies, and they are the embodiment of core competencies of students' development in entrepreneurship.

\subsection{Study on Core Competency of College Entrepreneurial Talents}

Entrepreneur is a person who undertakes risk for gaining profit in the business venture [7]. Entrepreneurial competency, as Hardeep Kaur and Dr. Anupama Bains said, is the individual characteristics [8]. In more detail, entrepreneurial competency is defined as hidden characteristics possessed by an entrepreneur which results in new ventures, creation, survival or growth [9]. Einar Rasmussen and Mike Wright refer to these competences as the "total ability of the entrepreneur to perform this role successfully [10]."Several studies have found positive relationship between core competencies of a person and his venture performance. To conclude, previous researches show that the core concept of entrepreneurial competencies, its measurement and its relationship to entrepreneurial performance and business success is in need of further research and development in practice [11]. This paper aims to explore the composition of core competencies of college entrepreneurial talents and to study the differences between the core competencies of College Students and successful entrepreneurs.

\section{Model Constructing of Core Competencies of Entrepreneurial Talents}

Entrepreneurial competencies, a combination of entrepreneurial quality and entrepreneurial discipline, are very important in college entrepreneurial education. At present, there are different classifications of entrepreneurial competencies in the educational circles. Based on the literature research on entrepreneurial competencies, this paper constructs a core competency model of entrepreneurial talents and tests it through factor analysis.

\subsection{Preliminary Model Constructing of Core Competencies of Entrepreneurial Talents}

David c. McClelland, an American psychologist, put forward the famous "Quality Iceberg Model " in 1973 that the individual quality is divided into two parts: one is "the part above iceberg", which is the external performance that includes the basic knowledge and skills; the other is "the part under iceberg", which is internal performance that is hard to measure, including social roles, self-images, traits and motivations [12]. This model is a milestone as it makes people realize that invisible factors have impacts on individual work just as visible ones do. By referring to the "Quality Iceberg Model", this paper divides the core competencies of entrepreneurial talents into four dimensions: entrepreneurial awareness, entrepreneurial knowledge, entrepreneurial ability and entrepreneurial quality. Under this 
framework, guided by the scientific, operable and comparable principles, this paper sorts 35 papers that mentioned entrepreneurial competencies in CNKI (China National Knowledge Infrastructure) and summarizes the factors of entrepreneurial competencies mentioned in these articles. And then in each dimension, the factors with a frequency greater than $30 \%$ are extracted as secondary index of entrepreneurial awareness, entrepreneurial knowledge, entrepreneurial ability and entrepreneurial quality. At last the core competencies model of entrepreneurial talents is obtained after expert assessment.

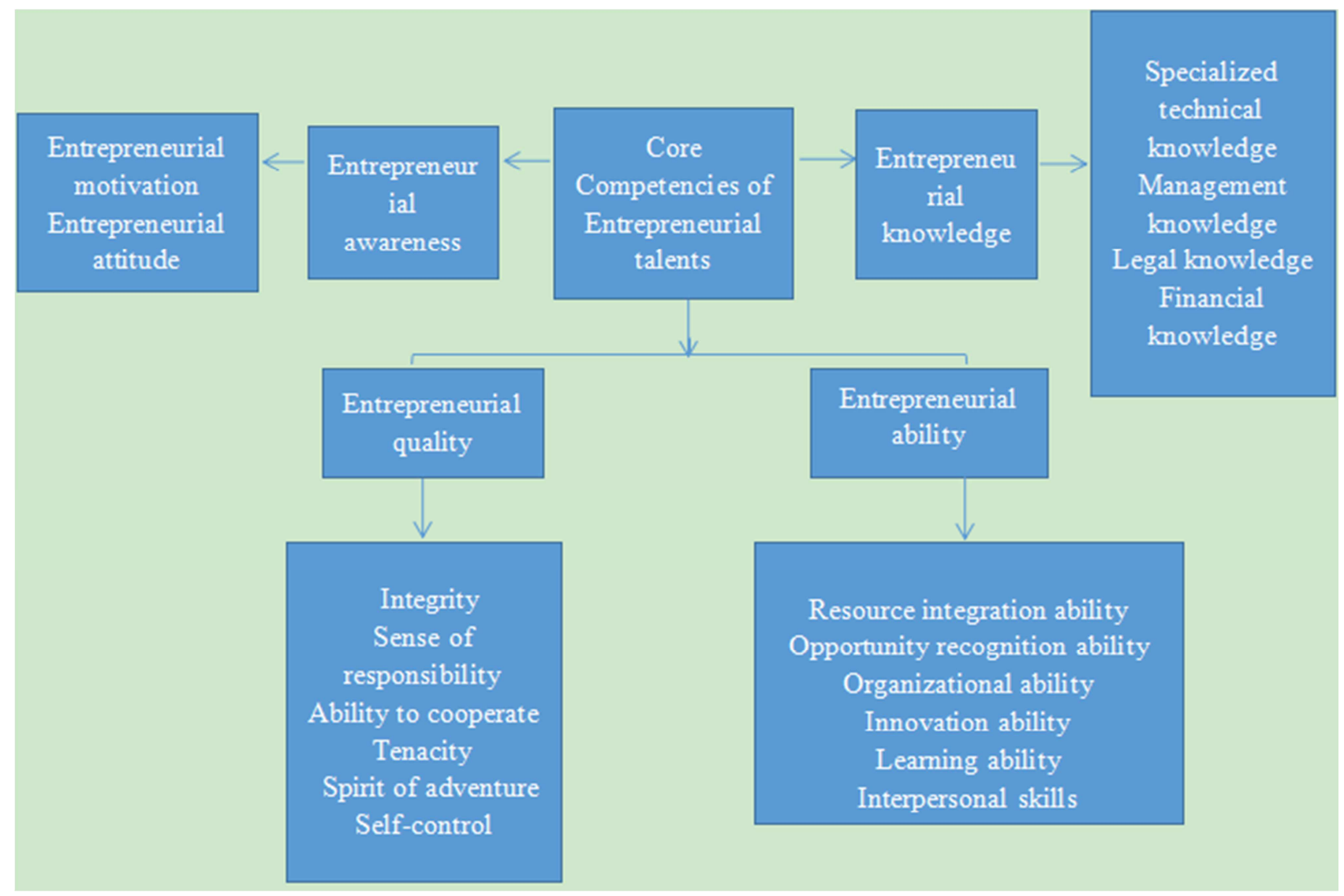

Figure 1. Core competency model of entrepreneurial talents.

\subsection{Data Collection}

Questionnaires are compiled based on the initially established model. The questionnaire is divided into two parts: the first part is the basic information of the participants, including gender, grade/age and profession; the second part is the core competencies measurement scale of entrepreneurial talents and in this part five-point Likert scale is applied. According to the description of the item, the participants should choose the one that they agree with from 5 options, that is, "Strongly disagree, Disagree, Neither agree nor disagree, Agree, Strongly agree". According to the choices of the participants in the second part, the scores of each factor and the four dimensions can be calculated (see appendix 1).

Two groups are included in the participants of the research: college entrepreneurial talents and entrepreneurs. The questionnaires for college entrepreneurial talents are only for those students with entrepreneurial intention. To the question "Have you ever thought of starting a business", if you answer "Yes", you need to answer the following questions. If you answer "No", you don't need to do that. The questionnaires are distributed in 7 universities, and students complete it through the SO JUMP (Wen Juan Xing, a software in China to conduct questionnaire survey). The participants of this research include undergraduate, postgraduate and doctoral students. Of the 1000 questionnaires issued, only 170 students have the intention to start a business, therefore the number of valid questionnaires is 170 . At the same time, through visiting the surrounding industrial parks and other ways, questionnaires are issued to 60 entrepreneurs for the purpose to compare the core competencies of college entrepreneurial talents with those of entrepreneurs.

\subsection{Factor Analysis of Core Competencies of Entrepreneurial Talents}

Before analyzing the questionnaires, it is necessary to check whether the design of the questionnaire is reasonable, whether the collected data matches the four dimensions, and whether the questions in each dimension provide consistent information. Therefore, exploratory and confirmatory factor analysis are needed. The collected 230 valid questionnaires (including college students and entrepreneurs) are analyzed by the software SPSS21.0 and the result shows that Alpha 
Coefficient is 0.900 , greater than 0.7 , which indicates that the questionnaire is of great reliability.

\subsubsection{Exploratory Factor Analysis}

To conduct exploratory factor analysis by the software SPSS21.0, the first step is to determine whether the exploratory factor analysis is applicable to the survey data through Kaiser-Meyer-Olkin (KMO) and Bartlett's test. On the condition that the KMO value is greater than 0.7 and the chi-square value of Bartlett's test is significant at least at the level of 0.05 [13], it is reasonable to carry out the exploratory factor analysis. Then, principal component analysis and varimax rotation are used to extract the factors whose Eigenvalue is greater than 1.

After KMO and Bartlett's test of the 18 questions about entrepreneurial competencies, the results show that the value of KMO is 0.831 , greater than the recommended 0.7 , that the chi-square value of Bartlett test is 3253.231, that the degrees of freedom is 153 , that significant coefficient is 0.000 . All these figures indicate that entrepreneurial competency scale is suitable for exploratory factor analysis (refer to Table 1)

Table 1. Results of KMO and Bartlett's Test.

\begin{tabular}{lll}
\hline Kaiser-Meyer-Olkin (KMO) measure of sampling adequacy & $\mathbf{0 . 8 3 1}$ \\
\hline & approximate chi-square & 3253.231 \\
Bartlett's test of sphericity & df (degree of freedom) & 153 \\
& Sig.(significance) & 0.000 \\
\hline
\end{tabular}

The exploratory factor analysis results (Table 2) show that after extracting the factors whose Eigenvalue is greater than 1, all items extracted 4 common factors. The percentages of explained variance of the 4 factors are $24.952 \%, 23.74 \%$ 、 $19.217 \%$ and $8.003 \%$ respectively and the cumulative percentages of explained variance of the 4 factors is $75.912 \%$. These figures reveal that the four factors explain most of the variation. At the same time, the factor loading of each item on the corresponding factor reaches to the minimum of 0.533 , and there is no situation where two factors are intersected in one item. By comparing corresponding items of the four factors and the dimension of college students' entrepreneurial competencies, it is showed that the results of exploratory factor analysis are completely consistent with the dimension division of the entrepreneurial competency theory. Therefore, the extracted components 1, 2, 3, 4 are named entrepreneurial quality, entrepreneurial knowledge, entrepreneurial ability and entrepreneurial awareness respectively.

Table 2. Results of the exploratory factor analysis.

\begin{tabular}{|c|c|c|c|c|}
\hline \multirow{2}{*}{ Dimensions } & \multicolumn{4}{|c|}{ Components } \\
\hline & 1 & 2 & 3 & 4 \\
\hline \multicolumn{5}{|l|}{ Entrepreneurial awareness } \\
\hline $\begin{array}{l}\text { If there is a good opportunity to start a business and a good job waiting for me, I will still choose to start a } \\
\text { business. }\end{array}$ & 0.043 & 0.033 & -0.111 & 0.533 \\
\hline $\begin{array}{l}\text { I hope to realize my value as well as gain fame and reputation by starting a business. } \\
\text { Entrepreneurial knowledge }\end{array}$ & -0.173 & 0.153 & -0.013 & 0.603 \\
\hline I have the professional knowledge and technology related to entrepreneurship. & -0.144 & 0.634 & 0.414 & 0.144 \\
\hline I have entrepreneurial management knowledge, such as human resource management, wealth management, etc & -0.01 & 0.754 & -0.027 & 0.313 \\
\hline $\begin{array}{l}\text { I have basic knowledge about the market economy theories and financial financing. } \\
\text { Entrepreneurial ability }\end{array}$ & 0.158 & 0.887 & 0.151 & 0.071 \\
\hline I am able to access and integrate all sorts of resources. & 0.006 & 0.369 & 0.801 & 0.223 \\
\hline I am good at finding and seizing opportunities. & 0.315 & 0.207 & 0.859 & -0.054 \\
\hline I am able to organize and coordinate human, material and financial resources to achieve my goals. & 0.358 & 0.206 & 0.836 & -0.141 \\
\hline I am able to learn new knowledge actively and keep learning. & 0.133 & 0.213 & 0.689 & -0.2 \\
\hline $\begin{array}{l}\text { I am able to take the initiative to make new friends and get along well with different types of people. } \\
\text { Entrepreneurial quality }\end{array}$ & 0.061 & 0.113 & 0.673 & -0.187 \\
\hline I will try my best to do what I have promised. & 0.596 & 0.027 & 0.168 & -0.177 \\
\hline I am able to take responsibility. & 0.817 & 0.388 & 0.201 & -0.026 \\
\hline $\begin{array}{l}\text { I am able to cooperate with my partners and listen to different opinions for the purpose to complete the task } \\
\text { together. }\end{array}$ & 0.888 & 0.247 & 0.164 & 0.094 \\
\hline No matter what difficulties I meet I will stick to what I have decided. & 0.691 & -0.12 & 0.066 & -0.081 \\
\hline I dare to try new things and explore risky filed. & 0.617 & 0.099 & 0.124 & 0.127 \\
\hline I am able to control my emotions and thoughts and discipline myself. & 0.877 & 0.041 & 0.083 & 0.153 \\
\hline Eigenvalue & 7.579 & 2.675 & 2.157 & 1.253 \\
\hline The total explained variance $(\%)$ & 24.952 & 48.692 & 67.909 & 75.912 \\
\hline
\end{tabular}

\subsubsection{Confirmatory Factor Analysis}

Based on the results of exploratory factor analysis, a 4-factor model is constructed via software Amos21.0 and the goodness of fit of the 4-factor model is determined by the fit indices. Table $2 \quad(\mathrm{CMIN} / \mathrm{DF} \quad=2.78<3, \quad \mathrm{SRMR}=0.045<0.08$, RMSEA $=0.067<0.08, \quad \mathrm{NFI}=0.93>0.90, \quad \mathrm{IFI}=0.93>0.9$, $\mathrm{CFI}=0.91>0.90, \mathrm{NNFI}=0.95>0.90)$ shows that all the fit indices 
are within the recommended range and the goodness of fit of the 4-factor model is excellent. What's more, the path coefficients of all items are greater than 0.5 and are of significance [14], showing that entrepreneurial competencies are of good validity.

Table 3. Results of entrepreneurial competencies' confirmatory factor analysis.

\begin{tabular}{|c|c|c|c|c|}
\hline Path & Estimate & S.E. & C.R. & $\mathbf{P}$ \\
\hline Specialized technical knowledge $<---$ entrepreneurial knowledge & 0.82 & 0.064 & 16.00 & $* * *$ \\
\hline Management knowledge<---entrepreneurial knowledge & 0.78 & 0.082 & 13.16 & $* * *$ \\
\hline Legal knowledge<---entrepreneurial knowledge & 0.89 & 0.089 & 19.38 & $* * *$ \\
\hline Financial knowledge<---entrepreneurial knowledge & 0.77 & 0.087 & 18.91 & $* * *$ \\
\hline Resource integration ability <---entrepreneurial ability & 0.79 & 0.058 & 16.80 & $* * *$ \\
\hline Opportunity recognition ability <---entrepreneurial ability & 0.78 & 0.097 & 18.94 & $* * *$ \\
\hline Organizational ability<---entrepreneurial ability & 0.85 & 0.080 & 11.08 & $* * *$ \\
\hline Learning ability<---entrepreneurial ability & 0.89 & 0.124 & 10.42 & $* * *$ \\
\hline Interpersonal skills<---entrepreneurial ability & 0.88 & 0.082 & 10.67 & $* * *$ \\
\hline Integrity<---entrepreneurial quality & 0.72 & 0.094 & 6.33 & 0.012 \\
\hline Sense of responsibility<----entrepreneurial quality & 0.91 & 0.085 & 9.22 & $* * *$ \\
\hline Ability to cooperate<----entrepreneurial quality & 0.97 & 0.091 & 8.76 & $* * *$ \\
\hline Tenacity<-----entrepreneurial quality & 0.78 & 0.089 & 7.94 & $* * *$ \\
\hline Spirit of adventure<----entrepreneurial quality & 0.90 & 0.089 & 17.92 & $* * *$ \\
\hline Entrepreneurial attitude<---entrepreneurial awareness & 0.84 & 0.082 & 18.68 & $* * *$ \\
\hline Fit index & \multicolumn{4}{|c|}{$\begin{array}{l}\mathrm{CMIN} / \mathrm{DF}=2.78 ; \mathrm{RMSEA}=0.067 ; \mathrm{SRMR}=0.045 ; \mathrm{NFI}=0.93 ; \mathrm{CFI}=0.91 ; \mathrm{NNFI}=0.95 ; \\
\mathrm{IFI}=0.93\end{array}$} \\
\hline
\end{tabular}

From the above factor analysis results, it can be seen that the questionnaire is of good reliability and validity, that the dimension division is reasonable and the data fit well with the questionnaire. Therefore, the results of the questionnaire survey can reflect the core entrepreneurial competencies of college entrepreneurial talents and entrepreneurs.

\section{Empirical Evaluation of the Core Competency Indices of Entrepreneurial Talents}

On the basis of the survey on entrepreneurs and experts in entrepreneurship, this article employs the analytic hierarchy process (AHP) to obtain the weights of the 4 dimensions and 18 indices of core competencies of entrepreneurial talents. Therefore, the importance of each entrepreneurial competency to entrepreneurial talents can be prioritized.

\subsection{The Construction of the Hierarchical Model of Core Competency Evaluation of Entrepreneurial Talents}

The evaluation of core competencies of entrepreneurial talents mainly involves four aspects, they are, entrepreneurial awareness, entrepreneurial knowledge, entrepreneurial ability and entrepreneurial quality. This paper constructs the following hierarchical model of core competency evaluation of entrepreneurial talents based on regarding the core competency evaluation of entrepreneurial talents as the target level, regarding the 4 dimensions, entrepreneurial awareness, entrepreneurial knowledge, entrepreneurial ability and entrepreneurial quality as the criteria level and regarding the 18 indices, such as entrepreneurial motivation and entrepreneurial attitude, as the program level.

Table 4. Hierarchical model of the core competency evaluation of entrepreneurial talents.

\begin{tabular}{lll}
\hline Target level & Criteria level & Program level \\
\hline & Entrepreneurial awareness $B_{1}$ & Entrepreneurial motivation $\mathrm{C}_{1}$ \\
& & Entrepreneurial attitude $\mathrm{C}_{2}$ \\
& & Specialized technical knowledge $\mathrm{C}_{3}$ \\
& Entrepreneurial knowledge $\mathrm{B}_{2}$ & Legal knowledge $\mathrm{C}_{4}$ \\
& & Management knowledge $\mathrm{C}_{5}$ \\
& & Financial knowledge $\mathrm{C}_{6}$ \\
& & Resource integration ability $\mathrm{C}_{7}$ \\
Core competency evaluation of & Opportunity recognition ability $\mathrm{C}_{8}$ \\
entrepreneurial talents A & Entrepreneurial ability $\mathrm{B}_{3}$ & Organizational ability $\mathrm{C}_{9}$ \\
& & Innovation ability $\mathrm{C}_{10}$ \\
& & Learning ability $\mathrm{C}_{11}$ \\
& & Interpersonal skills $\mathrm{C}_{12}$ \\
& & Integrity $\mathrm{C}_{13}$ \\
& & Sense of responsibility $\mathrm{C}_{14}$ \\
& & Ability to cooperation $\mathrm{C}_{15}$ \\
& & Tenacity $\mathrm{C}_{16}$ \\
& Entrepreneurial quality $\mathrm{B}_{4}$ & Spirit of adventure $\mathrm{C}_{17}$ \\
& & Self-control $\mathrm{C}_{18}$ \\
\hline
\end{tabular}




\subsection{Calculation of w (Factor Weight Vector of Criteria Level)}

\subsubsection{To Construct Judgment Matrix A}

$$
A=\left(\begin{array}{cccc}
1 & 1 / 2 & 1 / 6 & 1 / 3 \\
2 & 1 & 1 / 4 & 1 / 2 \\
6 & 4 & 1 & 2 \\
3 & 2 & 1 / 2 & 1
\end{array}\right)
$$

\subsubsection{To Calculate w (Factor Weight Vector of Criteria Level)}

The weight vector $\mathrm{w}$ is calculated by extracting the root and the following part is the calculation process.

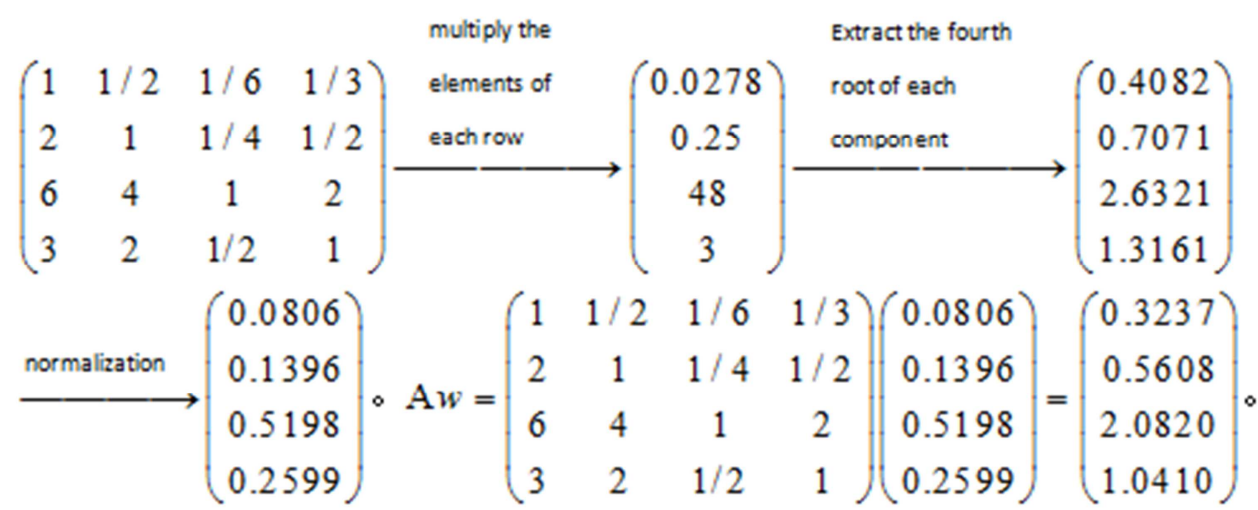

Figure 2. The process of calculation of $w$ (factor weight vector of criteria level).

$$
\lambda_{\max }=\frac{1}{n} \sum_{i=1}^{n} \frac{(\mathrm{A} w)_{i}}{(w)_{i}}=4.0104, \text { C.I. }=\frac{\lambda_{\max }-n}{n-1}=\frac{4.0104-4}{3}=0.0035, \text { C.R. }=\frac{\text { C.I. }}{\text { R.I. }}=\frac{0.0035}{0.89}=0.0039 \text {. }
$$

As the consistency ratio is 0.0039 , less than 0.1 , the judgement matrix A satisfies the requirement of consistency. So similarly, w, the factor weight vector of the program level, is calculated as follows.

$\mathrm{w} 1=(0.6667,0.3333)$,

$\mathrm{w} 2=(0.5695,0.0755,0.2433,0.1117)$,

$\mathrm{w} 3=(0.0576,0.03555,0.1152,0.235,0.1553,0.0815)$,

$\mathrm{w} 4=(0.412,0.0596,0.1639,0.2406,0.0843,0.0396)$.

\begin{tabular}{|c|c|c|c|c|c|}
\hline \multirow{2}{*}{ Level } & $\mathbf{B}_{1}$ & $\mathbf{B}_{2}$ & $\mathbf{B}_{3}$ & $\mathbf{B}_{4}$ & \multirow{2}{*}{ Synthetic weight } \\
\hline & 0.0806 & 0.1396 & 0.5198 & 0.2599 & \\
\hline $\mathrm{C}_{1}$ & 0.6667 & 0 & 0 & 0 & 0.0537 \\
\hline $\mathrm{C}_{2}$ & 0.3333 & 0 & 0 & 0 & 0.0269 \\
\hline $\mathrm{C}_{3}$ & 0 & 0.5695 & 0 & 0 & 0.0795 \\
\hline $\mathrm{C}_{4}$ & 0 & 0.0755 & 0 & 0 & 0.0105 \\
\hline $\mathrm{C}_{5}$ & 0 & 0.2433 & 0 & 0 & 0.0340 \\
\hline $\mathrm{C}_{6}$ & 0 & 0.1117 & 0 & 0 & 0.0156 \\
\hline $\mathrm{C}_{8}$ & 0 & 0 & 0.3555 & 0 & 0.1848 \\
\hline $\mathrm{C}_{9}$ & 0 & 0 & 0.1152 & 0 & 0.0599 \\
\hline $\mathrm{C}_{10}$ & 0 & 0 & 0.235 & 0 & 0.1222 \\
\hline $\mathrm{C}_{11}$ & 0 & 0 & 0.1553 & 0 & 0.0807 \\
\hline $\mathrm{C}_{12}$ & 0 & 0 & 0.0815 & 0 & 0.0424 \\
\hline $\mathrm{C}_{13}$ & 0 & 0 & 0 & 0.412 & 0.1071 \\
\hline $\mathrm{C}_{14}$ & 0 & 0 & 0 & 0.0596 & 0.0155 \\
\hline $\mathrm{C}_{16}$ & 0 & 0 & 0 & 0.2406 & 0.0625 \\
\hline $\mathrm{C}_{17}$ & 0 & 0 & 0 & 0.0843 & 0.0219 \\
\hline $\mathrm{C}_{18}$ & 0 & 0 & 0 & 0.0396 & 0.0103 \\
\hline
\end{tabular}

\subsection{Calculation of the Synthetic Weight}

Table 5. Calculation of the sequencing weight vector of synthetic weight. 
In conclusion, the evaluation index weight of entrepreneurial competencies of college students can be seen in the Table 6 .

Table 6. Evaluation index weight of entrepreneurial competencies of college students.

\begin{tabular}{lllll}
\hline First-class indices & Weight of first-class indices & Second-class indices & Weight of second-class indices & Synthetic weights \\
\hline Entrepreneurial & \multirow{2}{*}{0.0806} & Entrepreneurial motivation & 0.6667 & 0.0537 \\
awareness & & Entrepreneurial attitude & 0.3333 & 0.0269 \\
& & Specialized technical knowledge & 0.5695 & 0.0795 \\
Entrepreneurial & \multirow{2}{*}{0.1396} & Legal knowledge & 0.0755 & 0.0105 \\
knowledge & & Management knowledge & 0.2433 & 0.0340 \\
& & Financial knowledge & 0.1117 & 0.0156 \\
& & Resource integration ability & 0.0576 & 0.0299 \\
Entrepreneurial & \multirow{2}{*}{0.5198} & Opportunity recognition ability & 0.3555 & 0.1848 \\
ability & & Organizational ability & 0.1152 & 0.0599 \\
& & Innovation ability & 0.235 & 0.1222 \\
& & Learning ability & 0.1553 & 0.0807 \\
& & Interpersonal skills & 0.0815 & 0.0424 \\
Entrepreneurial & \multirow{2}{*}{0.2599} & Integrity & 0.412 & 0.1071 \\
quality & & Sense of responsibility & 0.0596 & 0.0155 \\
& & Ability to cooperate & 0.1639 & 0.0426 \\
& Tenacity & 0.2406 & 0.0625 \\
\end{tabular}

\section{Analysis of the Status of Core Competencies of College Entrepreneurial Talents}

The $1-5$ choices in the questionnaire are assigned to the scores of $0,25,50,75,100$ in order. Through analyzing the valid questionnaires of 170 college entrepreneurial talents and 60 entrepreneurs, the scores that the two groups get in each dimension can be obtained (Table 7). By combining the index weights calculated by the AHP (Analytic Hierarchy Process), the difference between the core competencies of college entrepreneurial talents and those of entrepreneurs can be compared.

Table 7. Comparison of core competencies between college entrepreneurial talents and entrepreneurs.

\begin{tabular}{|c|c|c|c|c|c|}
\hline First-class indices & $\begin{array}{l}\text { College entrepreneurial } \\
\text { talents }\end{array}$ & Entrepreneurs & Second-class indices & $\begin{array}{l}\text { College entrepreneurial } \\
\text { talents }\end{array}$ & Entrepreneurs \\
\hline \multirow{3}{*}{$\begin{array}{l}\text { Entrepreneurial } \\
\text { awareness }\end{array}$} & \multirow{3}{*}{63.68} & \multirow{3}{*}{77.5} & Entrepreneurial motivation & 64.12 & 75 \\
\hline & & & Entrepreneurial attitude & 63.24 & 80 \\
\hline & & & Specialized technical knowledge & 67.06 & 48.75 \\
\hline \multirow{5}{*}{$\begin{array}{l}\text { Entrepreneurial } \\
\text { knowledge }\end{array}$} & \multirow{3}{*}{71.51} & \multirow{3}{*}{52.81} & Legal knowledge & 75.74 & 56.25 \\
\hline & & & Management knowledge & 68.24 & 50 \\
\hline & & & Financial knowledge & 75 & 55.25 \\
\hline & \multirow{6}{*}{71.47} & \multirow{6}{*}{76.46} & Resource integration ability & 65.74 & 75 \\
\hline & & & Opportunity recognition ability & 73.38 & 76.25 \\
\hline \multirow{6}{*}{$\begin{array}{l}\text { Entrepreneurial } \\
\text { ability }\end{array}$} & & & Organizational ability & 73.82 & 75 \\
\hline & & & Innovation ability & 65.88 & 73.75 \\
\hline & & & Learning ability & 75.15 & 83.75 \\
\hline & & & Interpersonal skills & 74.85 & 75 \\
\hline & \multirow{6}{*}{69.63} & \multirow{6}{*}{77.5} & Integrity & 64.56 & 83.75 \\
\hline & & & Sense of responsibility & 73.24 & 86.25 \\
\hline \multirow{4}{*}{$\begin{array}{l}\text { Entrepreneurial } \\
\text { quality }\end{array}$} & & & Ability to cooperate & 72.65 & 75 \\
\hline & & & Tenacity & 63.68 & 78.75 \\
\hline & & & Spirit of adventure & 71.76 & 66.25 \\
\hline & & & Self-control & 71.91 & 75 \\
\hline The overall scores & 69.07 & 71.07 & & & \\
\hline
\end{tabular}

\subsection{Comparison of the Core Competencies of College Entrepreneurial Talents and Entrepreneurs}

The data in the evaluation index weight of entrepreneurial competencies of college students (Table 6) show that entrepreneurial ability has the largest weight which is followed by entrepreneurial quality, entrepreneurial knowledge and entrepreneurial awareness. These data illustrate that experts believe that entrepreneurial ability is the most important to entrepreneurial talents.

\subsubsection{Holistic Comparison}

From the perspective of overall score that college entrepreneurial talents and entrepreneurs get in the core competencies, entrepreneurs get 71.07 points, which is slightly higher than the 69.07 points of college entrepreneurial talents. Hence in terms of total scores, the 
two groups are of little difference. It is found that the scores that entrepreneurs get in entrepreneurial awareness, entrepreneurial ability and entrepreneurial quality are all higher than the scores of college entrepreneurial talents in these dimensions by comparing the 4 dimensions of core competencies. Of the 4 dimensions, entrepreneurial ability and entrepreneurial quality are the most important to entrepreneurial talents. Therefore, it can be determined that the overall competencies of entrepreneurs are higher than those of college entrepreneurial talents and there is a significant gap between them.

Further studies have found that entrepreneurs have stronger entrepreneurial awareness. The score gap in entrepreneurial awareness is the widest, which indicates that entrepreneurs have stronger passion toward entrepreneurial activities and firmer intention to start businesses. Though college entrepreneurial talents have entrepreneurial awareness, their entrepreneurial awareness is not firm and they easily change their decisions due to the influence of external factors. In addition, it is worth noting that entrepreneurs only get 52.81 points in entrepreneurial knowledge, far lower than the score of college entrepreneurial talents, who get 71.51 points in entrepreneurial knowledge. It can also be seen from the background information in the questionnaire that most of the entrepreneurs graduated with a three-year college diploma and the overall educational background of entrepreneurs is not as good as that of college students. However, these entrepreneurs still achieve success by virtue of their own strong ability and excellent quality, which shows that successful entrepreneurship is the result of multiple factors and education is only one of them.

\subsubsection{Indices Comparison}

From the comparison of 18 second-class indices, it is found that the scores that college entrepreneurial talents get in these indices are close, with scores ranging from 60 to 80 . However, the scores of entrepreneurs vary greatly, ranging from 40 to 90 . The reason behind the difference is that college students in the information age have more access to knowledge and information and have more opportunities to participate in various activities. What's more, as China recently advocates the comprehensive development and quality education, contemporary college students develop in a balanced way with a wide range of knowledge, broad vision and rich experience, which is also an outstanding advantage of college entrepreneurial talents [15].

For entrepreneurs, their strengths are distinct and their weaknesses are also distinct. For example, entrepreneurs get the lowest score of 48.75 points in the aspect of specialized technical knowledge. However, the biggest weight of specialized technical knowledge in the dimension of entrepreneurial knowledge (refer to Table 6) demonstrates that both experts and entrepreneurs recognize the importance of specialized technical knowledge. By contrast, college entrepreneurial talents get 67.06 points in specialized technical knowledge, a relatively higher score. The same is true for legal knowledge, management knowledge and financial knowledge which are subordinate to entrepreneurial knowledge. However, entrepreneurs get higher scores than college entrepreneurial talents in most of other indices. Of these indices, the entrepreneurial attitude and sense of responsibility of entrepreneurs are significantly better than those of college students. Difference is striking in the remaining indices except interpersonal skills, which is closely related to the family background, age, years to education, learning/working environment and so on.

\subsection{The Core Competency Status of College Entrepreneurial Talents}

\subsubsection{Weak Entrepreneurial Awareness and Infirm Entrepreneurial Attitude}

The study issues 1000 questionnaires in 7 universities. Only $17 \%$ of the students have the idea of starting a business and the majority of college students choose to find a job or go to further study as the best choice, which exposes the problem that the entrepreneurial awareness of college students is weak at large. The survey on 170 college entrepreneurial talents shows that the least developed one of the four core competencies is entrepreneurial awareness which is far behind that of entrepreneurs' entrepreneurial awareness. Among the 18 secondary indices, entrepreneurial attitude gets the lowest score of 63.24 points. As for the question "if there is a good opportunity to start a business but at the same time a good job is waiting for me, I will still choose to start a business", 92\% of the students choose "Disagree" or "Neither agree nor disagree", stating that these students are infirm in entrepreneurial attitude and are likely to be disturbed by other factors although they have entrepreneurial ideas.

\subsubsection{Heavily Weighted Entrepreneurial Ability and Entrepreneurial Quality with a Low Level}

The result of AHP (Analytic Hierarchy Process) reveals that the most heavily weighted dimension is entrepreneurial ability with a weight of 0.5198 , followed by entrepreneurial quality with a weight of 0.2599 , which signifies that these two competencies are the most crucial to entrepreneurial talents, especially entrepreneurial ability. However, the results of the survey reveal that the entrepreneurial ability and entrepreneurial quality of college entrepreneurial talents are not outstanding and are far behind those of entrepreneurs. Gap is particularly significant in the indices of resource integration ability, innovation ability, sense of responsibility and tenacity.

\subsubsection{Balanced Overall Development and Abundant Entrepreneurial Knowledge}

Table 7 shows that there is not much difference in the development of the four core competencies of college entrepreneurial talents. The score gap between college entrepreneurial talents is only 7.83 while the score gap between entrepreneurs is 23.65. The score gap contrast demonstrates that the core competencies of college 
entrepreneurial talents develop in a more balanced way. Of the four first-class indices, college entrepreneurial talents do well in the dimension of entrepreneurial knowledge which is the only index where college entrepreneurial talents get the score of 71.51 points, much higher than entrepreneurs. Abundant entrepreneurial knowledge is the advantage of college entrepreneurial talents in the entrepreneurial activities.

\section{Suggestions to Cultivate the Core Competencies of Entrepreneurial Talents}

\subsection{To Conduct Tribulation Training and Exchange Entrepreneurial Experiences}

Interviews with sampled college students find that a large number of students are unwilling to start a business because they cannot bear the consequences of failure, and they are not well psychologically prepared for setbacks. Nowadays, the majority of college students are the only children who live in a good environment. Little frustration in life may make them feel depressed as they have few life experiences, let alone to carry out entrepreneurial activities which are full of risk [16]. Therefore, it is necessary for colleges and universities to carry out hardships education to guide students to face failure with right mindset. What's more, colleges and universities should make plans to arrange students to participate in social training and campus competitions. Because when students have opportunities to experience failure, they are more psychologically prepared to face the next one.

In addition, when it comes to entrepreneurship, students are more likely to see its risky side while ignoring the sense of achievement in the process of entrepreneurship as students have no real entrepreneurial experience. Colleges and universities should invite entrepreneurs who have entrepreneurial experiences to give lectures to students so that they can communicate with entrepreneurs face to face and have a more comprehensive and objective understanding of entrepreneurship.

\subsection{To Implement Entrepreneurial Education and Promote Entrepreneurial Practice}

Entrepreneurial ability and entrepreneurial quality have great impacts on entrepreneurial activities, but the development of college entrepreneurial talents in the two aspects do not achieve the ideal level. The reason is that though many college students have entrepreneurial ideas, they have not received any systematic entrepreneurial training, which causes that the understanding of college students toward entrepreneurship is incomplete and they have no idea how to improve their entrepreneurial ability. The interviews find that only a small number of students have taken entrepreneurial education courses and many students even do not know whether their colleges offer entrepreneurship courses or carry out entrepreneurial activities. Among the 7 universities, Students from 3 universities say there is no entrepreneurial education course. It can be seen that college entrepreneurial education is not completely implemented. In order to encourage many potential entrepreneurs to realize their entrepreneurial dreams through starting their own businesses, colleges and universities should implement entrepreneurial education and promote entrepreneurial practice comprehensively. The content of entrepreneurial education course should meet the demands of students, including both ability training and moral education; including both theoretical interpretation and practical support. The form of education should be diversified, including entrepreneurial plan competition, team-coordinated entrepreneurship, simulated entrepreneurial activities, etc. Besides, there is a difference between the demand of enterprises and colleges for entrepreneurial talents, which leads to low enthusiasm for cooperation between both parties [17]. Hence, efforts should be extensively made to carry out college-enterprise cooperation so that students can practice in real enterprises, sharp their abilities and hone their characters. Finally, it is difficult to improve resource integration ability, innovation ability, sense of responsibility and tenacity in the campus. Therefore, colleges and universities should create opportunities for students to participate in resource integration process and the research and development of the product, which is of great help to cultivate the entrepreneurial quality of students.

\subsection{To Implement Entrepreneurship Policies and Offer Entrepreneurship Opportunities}

In order to encourage college students to start their own businesses and make innovation, China has introduced lots of entrepreneurial preferential policies to provide conveniences in terms of loans, taxation and procedures, and provide guidance in the operation of enterprises. Although the overall entrepreneurial competencies need to be improved, balanced overall development and abundant knowledgeable are still the advantages of college students in the process of starting businesses. Therefore, colleges and universities should offer strong support to improve the status quo of the college entrepreneurial talents. First, colleges and universities should vigorously publicize preferential policies to students to strengthen their confidence and reduce resistance to entrepreneurship. At the same time, colleges and universities should also take a series of supporting measures to improve the entrepreneurial efficiency and success rate of entrepreneurial talents. Secondly, the college graduates are vulnerable to encounter setbacks in the start-up stage as they have little entrepreneurial experiences and few social networks. Colleges and universities can make use of its own resources and influence to provide some excellent entrepreneurial talents with opportunities to cooperate with enterprises or to get trained in enterprises. Outstanding alumni or local entrepreneurs can also be invited to provide one-to-one assistance to college students who are about to start their own businesses. 


\section{Conclusion}

By investigating and comparing the core competency status of college entrepreneurial talents and entrepreneurs, the paper finds that there is a certain gap between the overall quality of college students' entrepreneurial talents and entrepreneurs. The entrepreneurial awareness, entrepreneurial ability and entrepreneurial quality of entrepreneurs are higher than that of college entrepreneurial talents. The main problems of college entrepreneurial talents are that entrepreneurial awareness is weak and easy to shake and entrepreneurial ability is not significant, even if analytic hierarchy process shows that entrepreneurial ability is the most important for entrepreneurial.

However, there are some advantages for college entrepreneurial talents. The study points that college entrepreneurial talents have rich entrepreneurial knowledge and are higher than entrepreneurs. Moreover, the development of core competences of college entrepreneurial talents are more comprehensive and balanced.

Therefore, colleges and universities should carry out entrepreneurship education based on the characteristics of college entrepreneurial talents. First of all, carrying out hardship training. Colleges and universities invite entrepreneurs to share entrepreneurial experiences to strengthen the entrepreneurial confidence of college students. Then carrying out systematic entrepreneurship education. Colleges and universities temper the entrepreneurial ability of college entrepreneurial talents through entrepreneurial practice. Finally, colleges and universities should provide strong support for entrepreneurial college students, provide policy advice, and expand entrepreneurial platforms, so that the ability of college students to start their own business can be displayed.

\section{Fund Project}

Research and Practice on Undergraduate Development Evaluation, a key project of Chongqing higher education teaching reform in 2016 (project No. 162005).

\section{References}

[1] The Number of Students in Higher Education Schools and Institutions [R/OL]. The Ministry of Education of the People's Republic of China (MOE), [2017-08-24]. http://www.moe.edu.cn/s78/A03/moe_560/jytjsj_2016/2016_q g/201708/t20170822_311603.html.

[2] Michaels Institute. Employment Report of Chinese College Students in 2018 [M]. Beijing: Social Science Literature Press, 2018.
[3] Roth, W. M. \& Jornet, A. Understanding Educational Psychology [M]. Bern: Springer, 2017.

[4] Robert, D. H., Michael, P. P., \& Dean, A. S. Entrepreneurship: Starting, Developing, and Managing a New Enterprise [M]. New York: McGraw-Hill Publishing Company, 2005.

[5] Partnership For 21st Century Skills. Framework for 21st Century Learning [EB/OL]. [2016-04-05]. http://www.p21.org/our-work/p21-framework.

[6] Release of Core Competencies of Chinese Student Development, People's Daily, September 14, 2016, edition 12.

[7] Bienkowska, D., \& Klofsten, M. Creating entrepreneurial networks: academic entrepreneurship, mobility and collaboration during $\mathrm{PhD}$ education [J]. Higher Education, 2012, 64 (2): 207-222.

[8] Kaur, H. \& Bains, A. Understanding the Concept of Entrepreneur Competency [J]. Journal of Business Management \& Social Sciences Research. 2013, 2 (11): 31-33.

[9] Autio, E., George, G., \& Alexy, O. International entrepreneurship and capability development-qualitative evidence and future research directions [J]. Entrepreneurship Theory and Practice, 2011, 35 (1): 11-37.

[10] Rasmussen \& Wright, M. How can universities facilitate academic spin-offs? An entrepreneurial competency perspective [J]. The Journal of Technology Transfer. 2015, 40 (5): 782-799.

[11] Fuller, A. W., \& Rothaermel, F. T. When stars shine: The effects of faculty founders on new technology ventures [J]. Strategic Entrepreneurship Journal, 2012, 6 (3): 220-235.

[12] Jiang Baowei, kong Qing. Study on Improvement of Entrepreneurial Quality of College Students Based on Iceberg Model [J]. Education Review, 2016, (9): 80-84.

[13] Lei Lei. Applied Linguistics Study Design and Statistics [M]. Wuhan: Huazhong University of Science and Technology Press, 2016: 191.

[14] WU Minglong. Structural Equation Model -- Operation and Application of AMOS [M]. Chongqing: Chongqing University Press, 2011: 212.

[15] Fan Liming. Core Competencies of Innovation and Entrepreneurship: Theoretical Research and Practical Exploration -- A Case Study of Shanghai University of Finance and Economics [J]. China Higher Education Research, 2016, (10): 83-87.

[16] Yu Shasha. Education Strategy Research on College Students' Entrepreneurship Awareness --A Case Study of Universities in Beijing [D]. Beijing: Beijing Forestry University, 2014.

[17] Ilmi, W. The Problems of 'Competency' and Alternatives from the Scandinavian Perspective of Bildung [J]. Journal of Curriculum Studies, 2015, 47 (3): 335. 